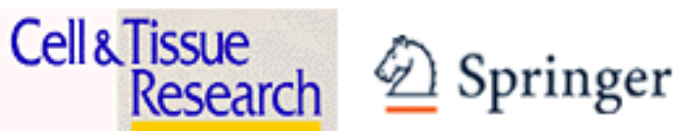

\section{Localization patterns of fibroblast growth factor 1 and its receptors FGFR1 and FGFR2 in the postnatal mouse retina}

\begin{tabular}{|c|c|}
\hline Journal: & Cell and Tissue Research \\
\hline Manuscript ID: & CTR-08-0393.R3 \\
\hline Manuscript Type: & Regular Article \\
\hline \multicolumn{2}{|l|}{$\begin{array}{r}\text { Date Submitted by the } \\
\text { Author: }\end{array}$} \\
\hline Complete List of Authors: & $\begin{array}{l}\text { Catalani, Elisabetta; Universita' della Tuscia, Dip. Scienze } \\
\text { Ambientali } \\
\text { Tomassini, Silvia; Universita' della Tuscia, Dip. Ecologia e Sviluppo } \\
\text { Economico Sostenibile } \\
\text { Dal Monte, Massimo; Universita' di Pisa, Dip. Biologia } \\
\text { Bosco, Luigi; Universita' della Tuscia, Dip. Ecologia e Sviluppo } \\
\text { Economico Sostenibile } \\
\text { Casini, Giovanni; Universita' della Tuscia, Dip. Scienze Ambientali }\end{array}$ \\
\hline Keywords: & $\begin{array}{l}\text { Development, Retinal ganglion cells, Amacrine cells, Horizontal } \\
\text { cells, Müller cells }\end{array}$ \\
\hline
\end{tabular}

\section{(4) ScholaroNE" \\ Manuscript Central}




\title{
Localization patterns of fibroblast growth factor 1 and its receptors FGFR1 and FGFR2 in the postnatal mouse retina
}

\author{
Elisabetta Catalani - Silvia Tomassini • Massimo Dal Monte • \\ Luigi Bosco • Giovanni Casini
}

Number of pages: $\mathbf{3 5}$

Number of figures: 8

Number of words in the abstract: $\mathbf{2 4 3}$

This work was supported by funding from Italian Ministry of Education

E. Catalani · G. Casini $(\Delta)$

Dipartimento di Scienze Ambientali, Università della Tuscia,

Largo dell'Università snc, Blocco D,

01100 Viterbo, Italy

e-mail: gcasini@unitus.it

S. Tomassini $\cdot$ L. Bosco

Dipartimento di Ecologia e Sviluppo Economico Sostenibile,

Università della Tuscia,

Viterbo, Italy

M. Dal Monte

Dipartimento di Biologia,

Università di Pisa,

Pisa, Italy 


\begin{abstract}
Fibroblast growth factors (FGFs) exert basic functions both during embryonic development and in the adult. In mammalian retinas, expression of FGFs and their receptors has been reported, however information on the organization of the FGF system is still incomplete. Here, we report detailed double label immunohistochemical investigations of the localization patterns of FGF1 and of its receptors FGFR1 and FGFR2 in adult and in early postnatal mouse retinas. In adult retinas, FGF1 is localized to ganglion cells, horizontal cells and photoreceptor inner and outer segments. FGFR1 is in ganglion cells and in Müller cells, while FGFR2 is primarily localized to ganglion cells and to the nuclei of Müller cells, in addition to glycine containing amacrine cells. During postnatal development, the patterns of FGF1, FGFR1 or FGFR2 immunostainings are similar to those in the adult, but transient FGF1 expressing cells are detected in the proximal inl before eye opening. These patterns are consistent with an important involvement of FGF1, FGFR1 and FGFR2 in ganglion cell maturation (during development) and survival (in the adult). In addition, FGF1 may affect amacrine cell development, while Müller cells appear to receive important regulation from both FGFR1 and FGFR2 throughout postnatal life. Finally, in immature retinas, large numbers of amacrine cells, including calbindin and glycine containing amacrine cells, display both FGF1 and FGFR2 immunoreactivities in their nuclei, suggesting an action of FGF1 on FGFR2 receptors during a restricted period of postnatal development for the maturation of these amacrine cells.
\end{abstract}

Keywords Development, Retinal ganglion cells, Amacrine cells, Horizontal cells, Müller cells 


\section{Introduction}

Fibroblast growth factors (FGFs) are polypeptide growth factors with diverse biological activities. The FGF family includes twenty-three members that mediate their cellular responses by binding to a family of four receptor tyrosine kinases designated FGFR1FGFR4 (Reuss and von Bohlen und Halbach 2003). These receptors are encoded by four distinct genes, and numerous FGFR isoforms derive from alternative splicing (Ornitz and Itoh 2001). The FGF binding to FGFRs is somewhat promiscuous, in that one receptor can be activated by several FGF ligands, but FGF1 is the only FGF that can activate all FGF receptor splice variants with high affinity (Zhang et al. 2006). FGFs also bind to heparin or heparan sulfate proteoglycans, which function as accessory molecules that regulate FGF binding and receptor activation (Ornitz and Itoh 2001). During embryonic development, FGFs play critical roles in morphogenesis by regulating cell proliferation, differentiation and migration (Bottcher and Niehrs 2005; Thisse and Thisse 2005). In the adult organism, FGFs play important roles in tissue repair, wound healing, stem cell self-renewal and angiogenesis (Presta et al. 2005; Yeoh and de Haan 2007).

In the central nervous system, FGFs exert basic functions both during embryonic development and in the adult. Indeed, FGF signaling is required during formation of the neural plate, while FGF signaling centers control growth and patterning of specific brain structures (Dono 2003; Ford-Perriss et al. 2001). In the adult brain, FGFs are involved in neuronal survival, adult stem cell activation and maintenance and repair of damaged neural tissues (Reuss and von Bohlen und Halbach 2003). 
Several members of the FGF family, as well as their receptors, are expressed in the developing vertebrate eye, and they play important roles in optic vesicle patterning (Hyer et al. 1998; Picker and Brand 2005; Yang 2004), lens formation (Lang 2004; Vogel-Hopker et al. 2000), neuronal differentiation (Russell 2003; Yang 2004), ganglion cell axonal growth and navigation (Russell 2003; Webber et al. 2003), and retinal vascularization (Rousseau et al. 2003). The functional actions of FGFs in mature retinas are primarily concerned with neuronal protection and survival (Blanco et al. 2000; Cuevas et al. 1998; Desire et al. 2000; Fontaine et al. 1998; Kinkl et al. 2003). FGFs and FGFRs have been localized, using in situ hybridization and/or immunohistochemistry, to adult or postnatal ferret, rat, bovine, pig, monkey and human retinas (see the discussion section for references). However, detailed localization studies clarifying the retinal cell populations expressing FGFs or their receptors are lacking, especially in the mouse retina where only scant information is available on the localization of these molecules (Gao and Hollyfield 1992; Jacquemin et al. 1990; Kurose et al. 2004). As a first step in the analysis of the FGF system in the mouse retina, in the present study we performed a thorough analysis of the immunohistochemical patterns of FGF1 and of its receptors FGFR1 and FGFR2 in adult mouse retinas as well as in retinas during postnatal development.

\section{Materials and methods}

Animals and tissue preparation 
Experiments were performed in compliance with the Italian law on animal care No. 116/1992, in accordance with the European Community Council Directive (EEC/609/86) and with guidelines established by the National Institutes of Health. All efforts were made to reduce both animal suffering and the number of animals used.

C57/BL6 mice at different postnatal ages were anesthetized by i.p. injection of Avertin (1.2\% tribromoethanol and $2.4 \%$ amylene hydrate in distilled water, $0.02 \mathrm{~mL} / \mathrm{g}$ body weight; Sigma, St. Louis, MO, USA) and killed by cervical dislocation. For the immunohistochemical stainings, the eyes were removed and immersion fixed in $4 \%$ paraformaldehyde in $0.1 \mathrm{M}$ phosphate buffer (PB), $\mathrm{pH} 7.4$, for $1 \mathrm{~h}$. The fixed eyes were transferred to $25 \%$ sucrose in $\mathrm{PB}$ and stored at $4{ }^{\circ} \mathrm{C}$. Retinal sections were cut perpendicularly to the vitreal surface at $10 \mu \mathrm{m}$ with a cryostat, mounted onto gelatincoated slides and stored at $-20{ }^{\circ} \mathrm{C}$. All retinas were cut with the same temporal-to-nasal orientation. For Western blots, the retinas, brain and pancreas of 10 adult mice were dissected out and treated as described below.

Antibodies

Rabbit polyclonal antibodies directed to FGF1, FGFR1 or FGFR2 were purchased from Santa Cruz Biotechnology (Santa Cruz, CA, USA). They were used at a dilution of 1:10 (FGF1) or 1:200 (FGFR1 and FGFR2). In addition, a mouse monoclonal antibody directed to FGF1 (Sigma, St. Louis, MO) was also used at 1:100 dilution. Doublelabeling immunofluorescence experiments were performed using the rabbit FGF1, FGFR1 or FGFR2 antibodies in conjunction with a mouse monoclonal antibody directed to glutamine synthetase (GS; Chemicon, Temecula, CA, USA), used at 1:500, which stains Müller cells; a mouse monoclonal antibody directed to protein kinase C 
(PKC; clone MC5, Sigma) used at 1:200, which stains rod bipolar cells; a rabbit polyclonal antibody directed to neurokinin 3 receptor (NK3; from Arlene Hirano of UCLA), used 1:400, which stains a population of OFF-type bipolar cells; a rabbit polyclonal antibody directed to $\gamma$-aminobutyric acid transporter-1 (GAT-1; Chemicon), used at 1:400, which stains GABAergic amacrine cells; a mouse monoclonal antibody directed to calbindin (Sigma), used at 1:2000, which stains horizontal cells; a mouse monoclonal antibody directed to $\beta$-tubulin III (Sigma), used at 1:400, which stains ganglion cells; or a rat monoclonal antibody directed to glycine (from David Pow, of the University of Newcastle, Australia), used at 1:1000, which stains glycinergic amacrine cells.

Immunohistochemical procedures

For immunohistochemical processing, the sections were washed in PB and incubated overnight at $4{ }^{\circ} \mathrm{C}$ in primary antibody diluted in $\mathrm{PB}$ containing $0.5 \%$ Triton $\mathrm{X}-100$. Following washes in $\mathrm{PB}$, the sections were incubated in secondary antibodies conjugated with Alexa Fluor fluorescent dyes (Alexa Fluor 546 or Alexa Fluor 488, Molecular Probes, Eugene, OR, USA) at a dilution of 1:200 in PB containing 0.5\% Triton X-100 for $1 \mathrm{~h}$ at room temperature. Then, the slides were coverslipped in a PBglycerin mixture. Some slides were coverslipped in a $0.1 \mathrm{M}$ PB-glycerin mixture containing $0.5 \mu \mathrm{g} / \mathrm{ml}$ of 4'-6-diamidino-2-phenylindole (DAPI, Sigma) to visualize the cell nuclei. Incubation in secondary antibody alone was performed to check for possible cross-reaction of the secondary antibody with the tissue. In addition, specificity of the FGF1, FGFR1 or FGFR2 immunostainings was evaluated by preadsorbing each 
antibody with $10 \mu \mathrm{M}$ of the corresponding peptide fragment overnight at $4{ }^{\circ} \mathrm{C}$. The preadsorbed antiserum was then used in place of the primary antibody. No immunostaining was detected in retinal sections in these control experiments.

In double-labeling experiments, the sections were incubated with a mixture of primary antibodies in PB containing $0.5 \%$ Triton $\mathrm{X}-100$, overnight at $4^{\circ} \mathrm{C}$. Following washes in PB, they were incubated in an appropriate mixture of secondary antibodies conjugated with Alexa Fluor 546 or Alexa Fluor 488 in PB containing $0.5 \%$ Triton X100 for 1-2 hours at room temperature. Finally, the sections were washed in PB and the slides were coverslipped in a PB-glycerin mixture.

In the case of double-labeling experiments with FGFR2 and GAT-1 or NK3, where both primary antibodies were made in rabbit, the sections were first incubated with one antibody, diluted in PB containing $0.5 \%$ Triton $\mathrm{X}-100$, for 3 hours at room temperature. Following washes in $\mathrm{PB}$, the sections were incubated in anti-rabbit fluoresceinconjugated Fab fragment (1:400, Santa Cruz) for 1.5 hours at room temperature and, subsequently, in anti-rabbit unlabeled Fab fragment (1:50, Santa Cruz) overnight at $4{ }^{\circ} \mathrm{C}$. After washes in PB, the sections were incubated with the other primary antibody, diluted in PB containing $0.5 \%$ Triton $\mathrm{X}-100$, for 3 hours at room temperature and, finally, with secondary antibodies conjugated with Alexa Fluor 546 at a dilution of 1:400 in PB containing $0.5 \%$ Triton $\mathrm{X}-100$ for 1.5 hours at room temperature. The slides were then washed and coverslipped. Control experiments included omission of either primary antibody to ascertain that the secondary antibodies (both directed to rabbit IgGs) did not cross-react.

Figure preparation and cell counting 
Confocal images were acquired with a Leitz laser confocal scanning microscope. Alternatively, immunofluorescence images were acquired using a 40x planNEOFLUAR Zeiss objective, a digital photocamera (Axiocam MRC) connected to a Zeiss microscope equipped with epi-fluorescence, Nomarski optics, and the Zeiss Axiovision 4 software. Images acquired with the confocal microscope or through the digital photocamera were sized and optimized for contrast and brightness using Adobe Photoshop (Adobe Systems, Mountain View, CA). Final images were saved at a minimum of 300 dpi.

To evaluate double labeled sections, immunostained cells were counted in immunofluorescence images acquired from slides deriving from three different retinas. At least five slides per retina, with six sections per slide, were sampled. A minimum of 500 cells were counted in each analysis.

Western blot

To measure protein levels of FGF1, FGFR1 and FGFR2, mouse retinas were homogenized in 10 mM Tris-HCl, pH 7.6 containing 5 mM EDTA, 3 mM EGTA, 250 $\mathrm{mM}$ sucrose, $1 \mathrm{mM}$ phenylmethylsulphonyl fluoride, $1 \mu \mathrm{M}$ peptistatin, $10 \mu \mathrm{g} / \mathrm{mL}$ leupeptin, and $2 \mu \mathrm{g} / \mathrm{mL}$ aprotinin, and centrifuged at $22,000 \times \mathrm{g}$ for $30 \mathrm{~min}$ at $4{ }^{\circ} \mathrm{C}$. The supernatant was used for FGF1 detection. The pellet was resuspended in $20 \mathrm{mM}$ HEPES, pH 7.4 containing 150 mM NaCl, 5 mM EDTA, 3 mM EGTA, 4 mg ndodecyl- $\beta$-maltoside and the proteinase inhibitors listed above and centrifuged at $22,000 \times \mathrm{g}$ for $30 \mathrm{~min}$ at $4^{\circ} \mathrm{C}$. The supernatant was used to detect FGFR1 or FGFR2. For 
positive controls, proteins extracted from brain or pancreas using the same procedure were used. Protein concentration was determined with the Bradford assay, using bovine serum albumin as a standard. Aliquots of each sample containing equal amounts of protein $(40 \mu \mathrm{g}$, except for pancreas samples assayed at both $40 \mu \mathrm{g}$ and $80 \mu \mathrm{g})$ were subjected to $10 \%$ sodium dodecyl sulphate-polyacrylamide gel electrophoresis. The gels were transblotted onto polyvinylidene difluoride membrane and blots were blocked for $1 \mathrm{~h}$ at room temperature with $3 \%$ milk. Blots were then incubated overnight at $4{ }^{\circ} \mathrm{C}$ with the Santa Cruz antisera directed to FGF1, FGFR1 or FGFR2 (1:100 dilution). For negative controls, the antibodies against FGF1, FGFR1 or FGFR2 were pre-incubated with the respective immunizing peptides overnight at $4{ }^{\circ} \mathrm{C}$ and then used on retinal extracts. Finally, blots were incubated for $2 \mathrm{~h}$ at room temperature with mouse antirabbit horseradish peroxidase-labeled secondary antibody (1:5000 dilution; Santa Cruz), and developed with the enhanced chemiluminescence detection method (Millipore, Billerica, MA).

\section{Results}

As shown in figure 1, antibodies directed to FGF1, FGFR1 or FGFR2 labeled protein bands corresponding to the expected molecular weights of these molecules. In particular, FGF1, FGFR1 and FGFR2 immunoreactive bands were observed in the retina, in the brain and in the pancreas. A second, very light FGFR1 immunoreactive protein band could be detected in brain and pancreas, but not in the retina. Increasing the amount of protein from the pancreas (from $40 \mu \mathrm{g}$ to $80 \mu \mathrm{g}$ - lanes 3 and 4 , 
respectively, in figure 1) determined an evident increase of the FGF1 immunoreactive band and a detectable increase of the FGFR1 immunoreactive band, while no changes could be appreciated in FGFR2 immunoreactivity. Together, these observations show that the antibodies used in this study specifically recognize FGF1, FGFR1 or FGFR2 in the central nervous system (retina and brain) and in peripheral organs (such as the pancreas).

FGF1, FGFR1 and FGFR2 immunostaining patterns in adult retinas

As shown in figure 2A, in adult mouse retinas, FGF1 immunolabeling was localized to numerous cell bodies both in the distal inner nuclear layer (inl) and in the ganglion cell layer ( $\mathrm{gcl}$ ), and to processes both in the inner and in the outer plexiform layers (ipl and opl, respectively). FGF1 immunolabeling was also detected in photoreceptor inner and outer segments, while no immunoreactive profiles were visible in the outer nuclear layer (onl). The intensely FGF1 immunoreactive cell somata in the distal inl as well as the processes arborizing in the opl (Fig. 2B) presumably belonged to horizontal cells. The FGF1 immunolabeling in the gcl and ipl (Fig. 2C) suggested FGF1 expression in ganglion cells. Both the monoclonal and the polyclonal FGF1 antibodies gave almost identical immunohistochemical patterns (Fig. 2J-L), further confirming the specificity of the immunostaining.

Double labels were performed using the FGF1 antiserum in conjunction with antibodies directed to calbindin or to $\beta$-tubulin III. Calbindin was used as a marker of horizontal cells (Haverkamp and Wässle 2000) and $\beta$-tubulin III was used as a marker of ganglion cells (Snow and Robson 1994; Watanabe et al. 1991). All the FGF1 
immunolabeled somata located in the distal inl also contained calbindin (Fig. 2D-F) and therefore they were horizontal cells. Moreover, all the calbindin immunoreactive processes in the opl also showed FGF1 immunoreactivity (Table 1). Concerning the FGF1 containing cells located in the gcl, they also contained $\beta$-tubulin III immunoreactivity, while all the $\beta$-tubulin III immunoreactive cells also contained FGF1 immunostaining (Table 1; Fig. 2G-I). FGF1 immunostaining was also visible in $\beta$ tubulin III immunolabeled bundles of ganglion cell axons. In the ipl, colocalization of FGF1 and $\beta$-tubulin III immunoreactivities was observed, indicating the presence of FGF1 in ganglion cell dendrites (left-oriented arrow in figure 2G-I). However, numerous FGF1 immunostained profiles in the ipl did not display $\beta$-tubulin III immunoreactivity (right-oriented arrows in figure 2G-I), indicating possible FGF1 expression in additional cell types. In particular, these profiles were mostly distributed within the ipl laminae adjacent to the gcl, and they could be bipolar cell axonal endings or parts of amacrine cell processes.

FGFR1 immunostaining in the adult mouse retina was extensively localized throughout the retinal layers. Its appearance was punctate, and it was particularly evident in the gcl and in stout processes spanning the whole thickness of the retina (Fig 3A). In particular, double labeling experiments using the FGFR1 antiserum in conjunction with $\beta$-tubulin III antibodies showed FGFR1 immunostaining in the cytosol of all ganglion cells (Table 1). In addition, FGFR1 was also localized in numerous fiber bundles formed by ganglion cell axons (Fig.3B-D). The FGFR1 immunoreactive processes oriented vertically through the retina belonged to Müller cells. Indeed, double labeling experiments using FGFR1 and GS antibodies showed extensive colocalization of the two markers (Fig. 3E-G). 
FGFR2 immunostaining in adult mouse retinas was confined to the inl and gcl, while faint immunolabeling was also in the photoreceptor inner segments (Fig. 4A). In particular, numerous FGFR2 immunopositive cell bodies were in the inl, and they were organized in 4 to 5 cellular rows (as numbered in figure $4 \mathrm{~A}$ ), with the mid-distal row containing the most intensely labeled profiles. In this cellular row, the intensity of FGFR2 immunostaining was consistent among different retinal preparations, while the staining in the other cellular rows of the inl was highly variable.

Double labeling experiments showed that FGFR2 immunostained cells were not horizontal cells, as colocalization of FGFR2 and calbindin immunostainings was not observed. In addition, the finding that FGFR2 was not in PKC immunolabeled rod bipolar cells (Fig. 4B-D) or in NK3 immunostained, cone bipolar cells (Fig. 4E-G) indicated that FGFR2 was unlikely to be localized to bipolar cells. The most intensely FGFR2 immunolabeled profiles in the inl belonged to Müller cells. Indeed, as shown in figure 4H-J, FGFR2 immunoreactivity appeared to reside within the nucleus of GS immunolabeled Müller cells. Localization of FGFR2 immunoreactivity to cell nuclei was confirmed in DAPI-stained retinal sections (inset of Fig. 4J). In addition, glycine containing amacrine cells were also FGFR2 immunopositive (Fig. 4K-M), while FGFR2 was not in GAT-1 immunolabeled amacrine cells. In sections in which both GS and glycine immunoreactive cells were labeled with the red secondary antibody, while FGFR2 immunoreactive cells were labeled with a green secondary antibody, we observed that there were no FGFR2 single labeled cell, indicating that the population of FGFR2 immunolabeled cells was constituted entirely of Müller cells or of glycinergic cells. Finally, double labelings using the $\beta$-tubulin III antibodies showed that FGFR2 is 
in the totality of ganglion cells (Table 1; Fig. 4N-P). In all cases, the FGFR2 immunostaining appeared to be mostly confined inside the cell bodies.

FGF1, FGFR1 and FGFR2 immunostaining patterns in developing retinas

The early postnatal mouse retina is composed of the gcl, the ipl and an undifferentiated layer distal to the ipl, indicated as neuroblastic layer (NBL), containing amacrine, bipolar, horizontal, and photoreceptor cells and their precursors (Schnitzer and Rusoff 1984). FGF1 immunolabeling was observed on the day of birth, or postnatal day (pnd) 0 (Fig. 5A), in numerous somata in the NBL and in the gcl of all retinal regions. In particular, FGF1 containing cells in the NBL were located either in its distal part or in its proximal part, adjacent to the ipl. At this age, the gcl appeared thicker than at older ages, and FGF1 immunoreactive somata were distributed throughout the thickness of gcl. At pnd 5, two distinct populations of FGF1 immunopositive cells were observed in the NBL (Fig. 5B). Large, intensely immunostained somata were seen near the presumptive location of the opl, which at this age is not yet morphologically discernible. In addition, smaller somata in the proximal NBL were migrating to a position adjacent to the ipl, where some immunostained processes could also be seen. A single row of densely packed, brightly immunofluorescent somata was detected in the gcl. At pnd 8, photoreceptor segments have started to differentiate, and they were labeled by FGF1 antibodies (Fig. 5C). In addition, at this age the opl has also differentiated and FGF1 immunostained cells, likely representing horizontal cells, could be observed in the distal inl adjacent to the opl. Numerous FGF1 immunoreactive cells were also in the inl adjacent to the ipl and in the gcl. At pnd 13 (Fig. 5D), which corresponds to the time of 
eye opening, the FGF1 immunolabeled horizontal cells were visible in the distal inl, the FGF1 immunolabeled cells in the proximal inl were no longer detected, and large sized FGF1 immunostained ganglion cells were in the gcl. Overall, the immunostaining pattern at pnd 13 was the same as that in the adult retina, with the exception that the FGF1 immunolabeling in the photoreceptor segments was more intense at this age than in the adult.

Double labeling experiments, using the FGF1 antiserum in conjunction with antibodies directed against calbindin or glycine, were performed to better characterize FGF1 localization patterns in the developing mouse retina. As shown in figure 5E, some of the FGF1 immunoreactive cells in the pnd 5 retina located in a position corresponding to the presumptive distal portion of the inl were calbindin immunoreactive. These cells could be interpreted as horizontal cells in the phase of positioning at their location or migrating amacrine cells. Putative amacrine cells migrating through the NBL and cells that had already reached their terminal position adjacent to the ipl displayed both FGF1 and calbindin immunoreactivities. All calbindin immunolabeled cells also contained FGF1, while only about $50 \%$ of the FGF1 immunoreactive cells also displayed calbindin immunostaining. Interestingly, the FGF1 immunostaining appeared to be confined to the cell nucleus. A similar pattern was observed in the pnd 5 retina with FGF1 and glycine double labelings. As shown in figure 5F-H, virtually all glycine containing amacrine cells, both in their migration through the NBL and at their terminal locations near the ipl, also contained FGF1 in their nuclei (Table 2). Localization of FGF1 immunoreactivity to cell nuclei was confirmed in DAPI-stained retinal sections (inset of Fig. 5E). 
The time course of FGFR1 localization patterns in postnatal mouse retinas is depicted in figure 6. The overlay of pseudo-colored immunofluorescence images on the Nomarski background helps identifying the exact location of FGFR1 immunostaining at the various developmental ages. FGFR1 immunolabeling was observed at pnd 0 (Fig. 6A) confined to the ipl and to presumed Müller cell endfeet near the outer limiting membrane. At pnd 5 (Fig. 6B), strong FGFR1 immunolabeling was still observed at the outer retinal margin. In addition, FGFR1 immunoreactive profiles, likely belonging to Müller cells, were detected in the mid-NBL, while putative FGFR1 immunoreactive amacrine cells were in the proximal NBL. Very scarce immunostaining was observed at this age in the ipl. Finally, many cells in the gcl displayed strong FGFR1 immunoreactivity. At pnd 8 (Fig. 6C), FGFR1 immunostaining assumed the characteristic patterns of Müller cells. In addition, numerous FGFR1 immunostained cells were observed in the inl adjacent to the ipl and in the gcl. At pnd 13 (Fig. 6D), the putative FGFR1 immunostained amacrine cells were no longer observed, and the FGFR1 immunostaining patterns were similar to those of the adult retinas.

The time course of FGFR2 localization patterns in postnatal mouse retinas is depicted in figure 7. In newborn retinas, FGFR2 immunoreactivity was observed in numerous cells bodies throughout the NBL, although immunolabeled somata were most densely packed in the mid-to-proximal portions of NBL. In addition, numerous FGFR2 immunostained cells were also observed in the multilayered gcl (Fig. 7A). At pnd 5 (Fig. 7B), numerous FGFR2 immunolabeled cells constituted two separate cohorts in the mid and in the proximal NBL. Those in the mid NBL displayed an elongated shape, while those in the proximal NBL were more rounded. FGFR2 immunolabeled cells were still observed in the gcl. At pnd 8 (Fig. 7C) and at pnd 13 (Fig. 7D), the FGFR2 
immunostaining patterns were similar to those of adult retinas, with intensely immunolabeled cells in the mid inl and in the gcl.

Double labeling experiments were performed using FGFR2 antibodies in conjunction with calbindin or glycine antibodies in retinas at pnd 5. As shown in figure 8, double labeled cells were observed in the proximal NBL. Virtually all calbindin containing (Fig. 8A-D) and glycine containing (Fig. 8E-G) amacrine cells also displayed FGFR2 immunostaining within their cell nuclei (Table 2). Localization of FGFR2 immunoreactivity to cell nuclei was confirmed in DAPI-stained retinal sections (inset of Fig. 8G).

\section{Discussion}

The data presented here provide the first detailed description of the localization patterns of FGF1 and its receptors FGFR1 and FGFR2 in the postnatal mouse retina. Previous works have reported the presence of different FGFs and/or FGF receptors in developing as well as in adult mammalian retinas; however this is the first study, to our knowledge, that identifies the cells carrying these molecules on the basis of specific immunohistochemical markers.

FGF1, FGFR1 and FGFR2 localization patterns in adult retinas: comparison with previous studies 
We have demonstrated that, in adult mouse retinas, FGF1 is localized to ganglion cells, horizontal cells and photoreceptors in their inner and outer segments. In addition, FGFR1 is in ganglion cells and in Müller cells. Finally, FGFR2 is primarily localized to ganglion cells and to the nucleus of Müller cells, while glycine containing amacrine cells have also been found to exhibit this receptor.

Localization of FGF1 (or "acidic" FGF) to the gcl has been reported, using immunohistochemistry or in situ hybridization, in different mammalian retinas including rat (Bugra and Hicks 1997; Lovicu et al. 1997; Noji et al. 1990), bovine (Caruelle et al. 1989; Jacquemin et al. 1990; Jacquemin et al. 1993), and monkey (Kitaoka et al. 1994) retinas. In addition, FGF1 immunostaining has been detected in the nerve fiber layer of bovine and human retinas (Caruelle et al. 1989), suggesting FGF1 expression by ganglion cells in these retinas. Finally, there is also a report of FGF1 mRNA in the gcl of mouse retinas (Jacquemin et al. 1990). Together, these observations indicate that the presence in the $\mathrm{gcl}$ is a conserved feature of FGF1 localization patterns in mammalian retinas. In particular, we have demonstrated that, in the mouse retina, this growth factor is present in all ganglion cells and not in displaced amacrine cells. Other members of the FGF family, such as FGF2 (or "basic" FGF), FGF5 and FGF15 have been reported in ganglion cells, or at least in the gcl, of mammalian retinas (Connolly et al. 1992; Gao and Hollyfield 1992; Kitaoka et al. 1994; Kurose et al. 2004; Miyashiro et al. 1998; Ohsato et al. 1997; Yamamoto et al. 1996). Regarding our finding of FGF1 localization to horizontal cells, previous papers have reported general, diffuse presence of FGF immunoreactivity or mRNA in the inl (Jacquemin et al. 1990; Jacquemin et al. 1993; Kitaoka et al. 1994; Lovicu et al. 1997; Noji et al. 1990), which may indicate the presence of FGF1 not only in horizontal cells 
but also in bipolar and/or amacrine cells. These observations may be consistent with our finding of FGF1 immunoreactivity within nerve fibers in the ipl which do not appear to belong to ganglion cell dendritic trees. Several studies suggest the presence of other members of the FGF family, mainly FGF2 but also FGF5, FGF9 and FGF21, in amacrine cells as well as in horizontal and/or bipolar cells (Cinaroglu et al. 2005; Connolly et al. 1992; Gao and Hollyfield 1992; Kitaoka et al. 1994; Kurose et al. 2004; Lovicu et al. 1997; Miyashiro et al. 1998; Ohsato et al. 1997; Yamamoto et al. 1996). We have also observed light FGF1 immunoreactivity in photoreceptor inner and outer segments, consistent with previous reports of the presence of FGF1 in photoreceptors or in the outer nuclear layer onl of different mammalian retinas (Bugra and Hicks 1997; Bugra et al. 1993; Caruelle et al. 1989; Jacquemin et al. 1990; Jacquemin et al. 1993; Kitaoka et al. 1994; Lovicu et al. 1997; Noji et al. 1990). FGF2, FGF5 and FGF9 have also been detected in photoreceptors, the onl or the interphotoreceptor matrix of mammalian retinas (Bugra and Hicks 1997; Cinaroglu et al. 2005; Hageman et al. 1991; Kitaoka et al. 1994; Lovicu et al. 1997; Ohsato et al. 1997).

Several reports confirm our finding of both FGFR1 and FGFR2 localization in ganglion cells. Indeed, FGFR1 and/or FGFR2 immunoreactivity or mRNA have been found in ganglion cells or in the gcl of ferret, rat, pig, and primate retinas (Blanquet and Jonet 1996; Cinaroglu et al. 2005; Cornish et al. 2004; Kinkl et al. 2002; Kinkl et al. 2003; Matsushima et al. 1996; Miyashiro et al. 1998; Quan et al. 1999; Sapieha et al. 2003; Wanaka et al. 1991; Yamamoto et al. 1996). Interestingly, FGFR3 and FGFR4 have also been localized to ganglion cells (Cinaroglu et al. 2005; Cornish et al. 2004; Kinkl et al. 2002; Kinkl et al. 2003). In addition to ganglion cells, we have also observed FGFR1 and FGFR2 in Müller cells. This finding is supported by studies in 
isolated Müller cells of the rat retina reporting the presence of FGFR1, FGFR2 and FGFR3 in these cells using RT-PCR and Western blotting, and the presence of FGFR2 and FGFR3 immunoreactivities in the cell nuclei (Cinaroglu et al. 2005). Concerning the presence of FGFR2 in amacrine cells, previous studies have reported FGFR2 immunoreactivity in the inl of rat, pig and human retinas (Cinaroglu et al. 2005; Kinkl et al. 2002; Kinkl et al. 2003; Sapieha et al. 2003), which may be consistent with our observations of FGFR2 immunoreactivity in glycinergic amacrine cells. Finally, FGFR1 and/or FGFR2 have been reported to be expressed in the outer retina (Blanquet and Jonet 1996; Kinkl et al. 2002; Kinkl et al. 2003; Ozaki et al. 2000; Quan et al. 1999; Sapieha et al. 2003; Torriglia et al. 1994; Valter et al. 2002), while we have only observed scarce FGFR2 immunofluorescence in photoreceptor inner segments. This partial discrepancy can be explained assuming some differences in the localization patterns of FGF receptors in different mammalian retinas or different antibody sensitivity (see, for instance, Gao and Hollyfield 1992).

FGF1, FGFR1 and FGFR2 in adult retinas: functional implications

Our data demonstrate that ganglion cells of the mouse retina contain FGF1, FGFR1 and FGFR2 immunoreactivities. In addition, other studies have shown the presence of other FGFs (mainly FGF2) and of all four FGFRs in the gcl of mammalian retinas. These observations suggest autocrine signaling mechanisms at the level of retinal ganglion cells. In particular, FGF1 and FGF2 have been shown to stimulate ganglion cell axonal regeneration (Lipton et al. 1988; Sapieha et al. 2003; Thanos et al. 1989), and to protect ganglion cells from ischemic damage (Cuevas et al. 1998; Unoki and LaVail 1994). In 
addition, FGF2 has been observed to enhance survival of adult ganglion cells in vitro (Hu and Ritch 1997) or after optic nerve damage (Sapieha et al. 2003; Sievers et al. 1987). In addition to FGF1 and FGF2, FGF9 has also been found to protect pig ganglion cells in vitro probably acting at the FGFR3 receptor. Taken together, these data indicate that different FGFs may cooperate to sustain and protect retinal ganglion cells in the adult retina and that studies clarifying these mechanisms may be of importance for the treatment of ocular diseases resulting in ganglion cell loss, such as, for instance, glaucoma.

Although FGFR1 and FGFR2 are plasma membrane receptors, their immunoreactivities are confined within cell bodies. FGF1 is known to be transported into cells in a receptor-dependent manner. The major proportion of FGF1 in the cytosol is translocated to the nucleus, phosphorylated, and then rapidly exported back to the cytosol where it is dephosphorylated and degraded (see for refs. Zakrzewska et al. 2006). This rapid degradation of FGF1 is likely to explain why we did not observe FGF1 immunoreactivity in the same cells were we observed FGFR1 or FGFR2. In the case of ganglion cells, where we observed FGF1 as well as FGFR1 and FGFR2 immunostainings, we can not exclude the possibility that, in principle, FGF1 is not synthesized by these cells but it is internalized together with its receptors and degraded with a slower time course. The nuclear roles of FGFs or FGFRs appear to involve cell proliferation and DNA transcription, and accordingly, nuclear FGFs have been detected in rapidly proliferating tissues (see for review Bryant and Stow 2005). The presence of FGFR1 and FGFR2 in neural cells of the retina is mainly in their cytosol, and it is unlikely to indicate a proliferative state of these cells. Instead, FGFR2 is consistently 
FGF1, FGFR1 and FGFR2 in developing retinas

FGFs and their receptors play a number of roles in eye development, including patterning of the optic vesicle, proliferation and differentiation of progenitor cells, and survival of neurons and photoreceptors (Fischer et al. 2002; Fischer and Reh 2002; Guillemot and Cepko 1992; Hicks and Courtois 1992; Hyer et al. 1998; Patel and McFarlane 2000). FGFs also promote neurite outgrowth (Chai and Morris 1999) and ganglion cell axon targeting (McFarlane et al. 1996; McFarlane et al. 1995). FGF1, FGFR1 and FGFR2 have been reported in embryonic and in postnatal developing mammalian retinas. In general, FGF1 has been detected around birth in rat and bovine retinas, predominantly in the gcl (Bugra and Hicks 1997; Bugra et al. 1993; Jacquemin et al. 1993; Lovicu et al. 1997), while FGFR1 and FGFR2 have been reported in the embryonic neuroblastic layer or in the $\mathrm{gcl}$ and inl of early postnatal rat retinas (Cinaroglu et al. 2005; Kinkl et al. 2002; Wanaka et al. 1991) as well as in cone photoreceptors of fetal monkeys (Cornish et al. 2004). Our observations of the FGF1, FGFR1 and FGFR2 developmental patterns in the mouse retina are in agreement with a possible role of these molecules in ganglion cell maturation. In addition, the presence of numerous FGF1 containing cells in the proximal inl throughout postnatal development up to the time of eye opening strongly suggests a role of FGF1 in the maturation of amacrine cells. Moreover, the presence of FGF1 in cells of the distal inl and in photoreceptor segments indicates an involvement of this growth factor in developmental 
regulation of horizontal cells and of photoreceptors. Together, these observations of FGF1 localization during the postnatal period suggest a role of FGF1 in the development of multiple retinal cell populations of the mouse retina.

Our double labeling experiments demonstrate that both FGF1 and FGFR2 immunoreactivities are present, in the immature retina, in the nuclei of calbindin or glycine containing cells. In particular, calbindin, in the mouse retina, is known to be expressed by horizontal cells, by a heterogeneous population of amacrine cells (which also includes the cholinergic amacrine cells) and by ganglion cells (Haverkamp and Wässle 2000). These observations strongly suggest that FGF1 acts on FGFR2 receptors during a restricted period of postnatal development for the maturation of calbindin and glycine containing amacrine cells, which, together, constitute the majority of amacrine cells.

During postnatal development, FGFR2 is also localized to the nuclei of those cells that we have identified as Müller cells in adult retinas, while FGFR1 appears to be confined to Müller cell cytosol, as in adult retinas. These observations suggest that Müller glial cells are subjected to actions mediated by FGFR1 and FGFR2 throughout life. Finally, the transient presence of FGFR1 in some presumed amacrine cells may indicate a role of this receptor in the maturation of some amacrine cell types.

Conclusions

The present study provides an exhaustive description of the localization patterns of FGF1 and of its receptors FGFR1 and FGFR2 in the adult as well as in the developing mouse retina. These patterns are consistent with an important involvement of these 
1

2

3

4

5

6

7

8

9

10

11

12

13

14

15

16

17

18

19

20

21

22

23

24

25

26

27

28

29

30

31

32

33

34

35

36

37

38

39

40

41

42

43

44

45

46

47

48

49

50

51

52

53

54

55

56

57

58

59

60

molecules in ganglion cell maturation (during development) and survival (in the adult). In addition, Müller cells appear to receive important regulation from both FGFR1 and FGFR2 throughout postnatal life. Finally, the presence of both FGF1 and FGFR2 in the nuclei of large numbers of amacrine cells during a developmental period before eye opening suggests important roles of these molecules in the maturation of the inner retina. 
Acknowledgments We wish to thank Dr. Arlene Hirano, of UCLA, for NK3 antibody;

Dr. David Pow, of the School of Biomedical Sciences, University of Newcastle, Australia, for glycine antibody. We also thank Dr. Cristiano Papeschi for animal care and Dr. Gabriella Gambellini (Interdepartmental Center of Electron Microscopy, University of Tuscia, Italy) for her help with confocal microscopy. 


\section{References}

Blanco RE, Lopez-Roca A, Soto J, Blagburn JM (2000) Basic fibroblast growth factor applied to the optic nerve after injury increases long-term cell survival in the frog retina. J Comp Neurol 423:646-658

Blanquet PR, Jonet L (1996) Signal-regulated proteins and fibroblast growth factor receptors: comparative immunolocalization in rat retina. Neurosci Lett 214:135-138

Bottcher RT, Niehrs C (2005) Fibroblast growth factor signaling during early vertebrate development. Endocr Rev 26:63-77

Bryant DM, Stow JL (2005) Nuclear translocation of cell-surface receptors: lessons from fibroblast growth factor. Traffic 6:947-954

Bugra K, Hicks D (1997) Acidic and basic fibroblast growth factor messenger RNA and protein show increased expression in adult compared to developing normal and dystrophic rat retina. J Mol Neurosci 9:13-25

Bugra K, Oliver L, Jacquemin E, Laurent M, Courtois Y, Hicks D (1993) Acidic fibroblast growth factor is expressed abundantly by photoreceptors within the developing and mature rat retina. Eur J Neurosci 5:1586-1595

Caruelle D, Groux-Muscatelli B, Gaudric A, Sestier C, Coscas G, Caruelle JP, Barritault D (1989) Immunological study of acidic fibroblast growth factor (aFGF) distribution in the eye. J Cell Biochem 39:117-128

Chai L, Morris JE (1999) Heparan sulfate in the inner limiting membrane of embryonic chicken retina binds basic fibroblast growth factor to promote axonal outgrowth. Exp Neurol 160:175-185

Cinaroglu A, Ozmen Y, Ozdemir A, Ozcan F, Ergorul C, Cayirlioglu P, Hicks D, Bugra K (2005) Expression and possible function of fibroblast growth factor 9 (FGF9) and its cognate receptors FGFR2 and FGFR3 in postnatal and adult retina. J Neurosci Res 79:329-339

Connolly SE, Hjelmeland LM, LaVail MM (1992) Immunohistochemical localization of basic fibroblast growth factor in mature and developing retinas of normal and RCS rats. Curr Eye Res 11:1005-1017

Cornish EE, Natoli RC, Hendrickson A, Provis JM (2004) Differential distribution of fibroblast growth factor receptors (FGFRs) on foveal cones: FGFR-4 is an early marker of cone photoreceptors. Mol Vis 10:1-14 
Cuevas P, Carceller F, Redondo-Horcajo M, Lozano RM, Gimenez-Gallego G (1998) Systemic administration of acidic fibroblast growth factor ameliorates the ischemic injury of the retina in rats. Neurosci Lett 255:1-4

Desire L, Courtois Y, Jeanny JC (2000) Endogenous and exogenous fibroblast growth factor 2 support survival of chick retinal neurons by control of neuronal neuronal bcl$\mathrm{x}(\mathrm{L})$ and bcl-2 expression through a fibroblast berowth factor receptor 1- and ERKdependent pathway. J Neurochem 75:151-163

Dono R (2003) Fibroblast growth factors as regulators of central nervous system development and function. Am J Physiol Regul Integr Comp Physiol 284:R867-881

Fischer AJ, Dierks BD, Reh TA (2002) Exogenous growth factors induce the production of ganglion cells at the retinal margin. Development 129:2283-2291

Fischer AJ, Reh TA (2002) Exogenous growth factors stimulate the regeneration of ganglion cells in the chicken retina. Dev Biol 251:367-379

Fontaine V, Kinkl N, Sahel J, Dreyfus H, Hicks D (1998) Survival of purified rat photoreceptors in vitro is stimulated directly by fibroblast growth factor-2. J Neurosci 18:9662-9672

Ford-Perriss M, Abud H, Murphy M (2001) Fibroblast growth factors in the developing central nervous system. Clin Exp Pharmacol Physiol 28:493-503

Gao H, Hollyfield JG (1992) Basic fibroblast growth factor (bFGF) immunolocalization in the rodent outer retina demonstrated with an anti-rodent bFGF antibody. Brain Res 585:355-360

Guillemot F, Cepko CL (1992) Retinal fate and ganglion cell differentiation are potentiated by acidic FGF in an in vitro assay of early retinal development.

Development 114:743-754

Hageman GS, Kirchoff-Rempe MA, Lewis GP, Fisher SK, Anderson DH (1991)

Sequestration of basic fibroblast growth factor in the primate retinal interphotoreceptor matrix. Proc Natl Acad Sci U S A 88:6706-6710

Haverkamp S, Wässle H (2000) Immunocytochemical analysis of the mouse retina. J Comp Neurol 424:1-23

Hicks D, Courtois Y (1992) Fibroblast growth factor stimulates photoreceptor differentiation in vitro. J Neurosci 12:2022-2033

Hu DN, Ritch R (1997) Tissue culture of adult human retinal ganglion cells. J Glaucoma 6:37-43 
Hyer J, Mima T, Mikawa T (1998) FGF1 patterns the optic vesicle by directing the placement of the neural retina domain. Development 125:869-877

Jacquemin E, Halley C, Alterio J, Laurent M, Courtois Y, Jeanny JC (1990) Localization of acidic fibroblast growth factor (aFGF) mRNA in mouse and bovine retina by in situ hybridization. Neurosci Lett 116:23-28

Jacquemin E, Jonet L, Oliver L, Bugra K, Laurent M, Courtois Y, Jeanny JC (1993) Developmental regulation of acidic fibroblast growth factor (aFGF) expression in bovine retina. Int J Dev Biol 37:417-423

Kinkl N, Hageman GS, Sahel JA, Hicks D (2002) Fibroblast growth factor receptor (FGFR) and candidate signaling molecule distribution within rat and human retina. Mol Vis 8:149-160

Kinkl N, Ruiz J, Vecino E, Frasson M, Sahel J, Hicks D (2003) Possible involvement of a fibroblast growth factor 9 (FGF9)-FGF receptor-3-mediated pathway in adult pig retinal ganglion cell survival in vitro. Mol Cell Neurosci 23:39-53

Kitaoka T, Aotaki-Keen AE, Hjelmeland LM (1994) Distribution of FGF-5 in the rhesus macaque retina. Invest Ophthalmol Vis Sci 35:3189-3198

Kurose H, Bito T, Adachi T, Shimizu M, Noji S, Ohuchi H (2004) Expression of Fibroblast growth factor 19 (Fgf19) during chicken embryogenesis and eye development, compared with Fgf15 expression in the mouse. Gene Expr Patterns 4:687693

Lang RA (2004) Pathways regulating lens induction in the mouse. Int J Dev Biol 48:783-791

Lipton SA, Wagner JA, Madison RD, D'Amore PA (1988) Acidic fibroblast growth factor enhances regeneration of processes by postnatal mammalian retinal ganglion cells in culture. Proc Natl Acad Sci U S A 85:2388-2392

Lovicu FJ, de Iongh RU, McAvoy JW (1997) Expression of FGF-1 and FGF-2 mRNA during lens morphogenesis, differentiation and growth. Curr Eye Res 16:222-230

Matsushima M, Ogata N, Takada Y, Tobe T, Yamada H, Takahashi K, Uyama M (1996) FGF receptor 1 expression in experimental choroidal neovascularization. Jpn J Ophthalmol 40:329-338

McFarlane S, Cornel E, Amaya E, Holt CE (1996) Inhibition of FGF receptor activity in retinal ganglion cell axons causes errors in target recognition. Neuron 17:245-254 
McFarlane S, McNeill L, Holt CE (1995) FGF signaling and target recognition in the developing Xenopus visual system. Neuron 15:1017-1028

Miyashiro M, Ogata N, Takahashi K, Matsushima M, Yamamoto C, Yamada H, Uyama M (1998) Expression of basic fibroblast growth factor and its receptor mRNA in retinal tissue following ischemic injury in the rat. Graefes Arch Clin Exp Ophthalmol 236:295300

Noji S, Matsuo T, Koyama E, Yamaai T, Nohno T, Matsuo N, Taniguchi S (1990) Expression pattern of acidic and basic fibroblast growth factor genes in adult rat eyes. Biochem Biophys Res Commun 168:343-349

Ohsato M, Hayashi H, Oshima K, Koji T, Nakane P (1997) In situ localization of basic fibroblast growth factor protein and mRNA in the retina. Ophthalmic Res 29:24-30

Ornitz DM, Itoh N (2001) Fibroblast growth factors. Genome Biol 2:REVIEWS3005

Ozaki S, Radeke MJ, Anderson DH (2000) Rapid upregulation of fibroblast growth factor receptor 1 (flg) by rat photoreceptor cells after injury. Invest Ophthalmol Vis Sci 41:568-579

Patel A, McFarlane S (2000) Overexpression of FGF-2 alters cell fate specification in the developing retina of Xenopus laevis. Dev Biol 222:170-180

Picker A, Brand M (2005) Fgf signals from a novel signaling center determine axial patterning of the prospective neural retina. Development 132:4951-4962

Presta M, Dell'Era P, Mitola S, Moroni E, Ronca R, Rusnati M (2005) Fibroblast growth factor/fibroblast growth factor receptor system in angiogenesis. Cytokine Growth Factor Rev 16:159-178

Quan MZ, Kosaka M, Watanabe M, Fukuda Y (1999) Localization of FGFR-1 in axotomized and peripheral nerve transplanted ferret retina. Neuroreport 10:3903-3907

Reuss B, von Bohlen und Halbach O (2003) Fibroblast growth factors and their receptors in the central nervous system. Cell Tissue Res 313:139-157

Rousseau B, Larrieu-Lahargue F, Bikfalvi A, Javerzat S (2003) Involvement of fibroblast growth factors in choroidal angiogenesis and retinal vascularization. Exp Eye Res 77:147-156

Russell C (2003) The roles of Hedgehogs and Fibroblast Growth Factors in eye development and retinal cell rescue. Vision Res 43:899-912 
Sapieha PS, Peltier M, Rendahl KG, Manning WC, Di Polo A (2003) Fibroblast growth factor-2 gene delivery stimulates axon growth by adult retinal ganglion cells after acute optic nerve injury. Mol Cell Neurosci 24:656-672

Schnitzer J, Rusoff AC (1984) Horizontal cells of the mouse retina contain glutamic acid decarboxylase-like immunoreactivity during early developmental stages. J Neurosci 4:2948-2955

Sievers J, Hausmann B, Unsicker K, Berry M (1987) Fibroblast growth factors promote the survival of adult rat retinal ganglion cells after transection of the optic nerve. Neurosci Lett 76:157-162

Snow RL, Robson JA (1994) Ganglion cell neurogenesis, migration and early differentiation in the chick retina. Neuroscience 58:399-409

Thanos S, Bahr M, Barde YA, Vanselow J (1989) Survival and Axonal Elongation of Adult Rat Retinal Ganglion Cells. Eur J Neurosci 1:19-26

Thisse B, Thisse C (2005) Functions and regulations of fibroblast growth factor signaling during embryonic development. Dev Biol 287:390-402

Torriglia A, Jeanny JC, Blanquet PR (1994) Immunohistochemical analysis of fibroblast growth factor receptor in bovine retina. Neurosci Lett 172:125-128

Unoki K, LaVail MM (1994) Protection of the rat retina from ischemic injury by brainderived neurotrophic factor, ciliary neurotrophic factor, and basic fibroblast growth factor. Invest Ophthalmol Vis Sci 35:907-915

Valter K, van Driel D, Bisti S, Stone J (2002) FGFR1 expression and FGFR1-FGF-2 colocalisation in rat retina: sites of FGF-2 action on rat photoreceptors. Growth Factors 20:177-188

Vogel-Hopker A, Momose T, Rohrer H, Yasuda K, Ishihara L, Rapaport DH (2000) Multiple functions of fibroblast growth factor-8 (FGF-8) in chick eye development. Mech Dev 94:25-36

Wanaka A, Milbrandt J, Johnson EM, Jr. (1991) Expression of FGF receptor gene in rat development. Development 111:455-468

Watanabe M, Rutishauser U, Silver J (1991) Formation of the retinal ganglion cell and optic fiber layers. J Neurobiol 22:85-96

Webber CA, Hyakutake MT, McFarlane S (2003) Fibroblast growth factors redirect retinal axons in vitro and in vivo. Dev Biol 263:24-34 
Yamamoto C, Ogata N, Matsushima M, Takahashi K, Miyashiro M, Yamada H, Maeda H, Uyama M, Matsuzaki K (1996) Gene expressions of basic fibroblast growth factor and its receptor in healing of rat retina after laser photocoagulation. Jpn J Ophthalmol 40:480-490

Yang XJ (2004) Roles of cell-extrinsic growth factors in vertebrate eye pattern formation and retinogenesis. Semin Cell Dev Biol 15:91-103

Yeoh JS, de Haan G (2007) Fibroblast growth factors as regulators of stem cell selfrenewal and aging. Mech Ageing Dev 128:17-24

Zakrzewska M, Krowarsch D, Wiedlocha A, Olsnes S, Otlewski J (2006) Structural requirements of FGF-1 for receptor binding and translocation into cells. Biochemistry 45:15338-15348

Zhang X, Ibrahimi OA, Olsen SK, Umemori H, Mohammadi M, Ornitz DM (2006) Receptor specificity of the fibroblast growth factor family. The complete mammalian FGF family. J Biol Chem 281:15694-15700 
Fig. 1 Western blots showing immunoreactivities for FGF1, FGFR1 and FGFR2 in mouse retinas. The antibodies labeled protein bands at the expected molecular weights (MW). Lanes: 1, retina; 2, brain; 3, pancreas (40 $\mu \mathrm{g}$ protein); 4, pancreas (80 $\mu \mathrm{g}$ protein); 5 , control with primary antibody pre-incubated with the immunizing peptide

Fig. 2 Patterns of FGF1 localization in the mouse retina. A: Extended focus of 3 confocal images from a cryostat section stained with FGF1 antibodies. In all figures (except panels $\mathrm{K}$ and $\mathrm{L}$ of the present figure), FGF1 immunostaining is obtained using the Santa Cruz antiserum. Immunolabeling is distributed to the photoreceptor inner (is) and outer (os) segments, to putative horizontal cells in the distal inner nuclear layer (inl), to processes in the inner plexiform layer (ipl) and to putative ganglion cells in the ganglion cell layer ( $\mathrm{gcl})$. B and C: Higher power of, respectively, putative FGF1 immunostained horizontal cells and ganglion cells. D-F: Confocal images from cryostat sections double labeled with FGF1 and calbindin. GI: Confocal images from sections double labeled with FGF1 and $\beta$-Tubulin III . J-L: Confocal images from sections double labeled with the rabbit FGF1 antiserum and the mouse FGF1 monoclonal antibody. Note that both antibodies resulted in almost identical immunostaining patterns. F, I and L are overlay images. onl, outer nuclear layer; opl, outer plexiform layer. Scale bars: $20 \mu \mathrm{m}$ in A and in L; $10 \mu \mathrm{m}$ in the other panels

Fig. 3 A: FGFR1 immunostaining pattern. B-D: Confocal images of a section double labeled with FGFR1 and $\beta$-Tubulin III . E-G: Confocal images of a section double 
labeled with FGFR1 and GS . Abbreviations as in figure 2. Scale bars: $20 \mu \mathrm{m}$ in A; $10 \mu \mathrm{m}$ in the other panels

Fig. 4 A: FGFR2 immunostaining pattern. Extended focus of 3 optical sections. B-D: Confocal images of a section double labeled with FGFR2 and PKC. E-G: Confocal images of a section double labeled with FGFR2 and NK3. H-J: Confocal images of a section double labeled with FGFR2 and GS. The inset in $\mathrm{J}$ shows FGFR2 immunoreactivity inside DAPI-stained cell nuclei. K-M: Confocal images of a section double labeled with FGFR2 and glycine. N-P: Confocal images of a section double labeled with FGFR2 and $\beta$-Tubulin III. Abbreviations as in figure 2. Scale bars: $20 \mu \mathrm{m}$ in $\mathrm{A} ; 10 \mu \mathrm{m}$ in $\mathrm{G}$ (which also refers to $\mathrm{B}-\mathrm{D}$ ), in $\mathrm{M}$ (which also refers to $\mathrm{H}-\mathrm{J})$, in $\mathrm{P}$, and in the inset in $\mathrm{J}$.

Fig. 5 A-D: Developmental patterns of FGF1 localization in the early postnatal mouse retina. E: Confocal image (extended focus of 5 optical sections) of a retinal section at pnd 5 double labeled with FGF1 and calbindin. Double labeled profiles appear yellow. The inset shows FGFR2 immunoreactivity inside DAPI-stained cell nuclei. F-H: Confocal images of a retinal section at pnd 5 double labeled with FGF1 and glycine. Note that the two glycine immunostained cells in the lower right corner of panels $\mathrm{G}$ and $\mathrm{H}$ do not display FGF1 immunostaining simply because their nuclei are not included in this optical section. These same cells showed FGF1 immunoreactivity in their nuclei in adjacent optical sections. Abbreviations as in figure 2. Scale bars: $20 \mu \mathrm{m}$ in $\mathrm{D}$ and in $\mathrm{E} ; 10 \mu \mathrm{m}$ in $\mathrm{H}$ and in the inset in $\mathrm{E}$. 
Fig. 6 Immunofluorescence photomicrographs showing FGFR1 immunostaining patterns in the early postnatal mouse retina (left) together with Nomarski images of the same retinal field (center) and overlays of pseudo-colored immunofluorescence staining and the corresponding Nomarski image (right). *Immunofluorescence in pieces of pigment epithelium that remained attached to the retina. Abbreviations as in figure 2. Scale bar: $20 \mu \mathrm{m}$

Fig. 7 Immunofluorescence photomicrographs showing FGFR2 immunostaining patterns in the early postnatal mouse retina (left) together with Nomarski images of the same retinal field (center) and overlays of pseudo-colored immunofluorescence staining and the corresponding Nomarski image (right). *Immunofluorescence in pieces of pigment epithelium that remained attached to the retina. Abbreviations as in figure 2. Scale bar: $20 \mu \mathrm{m}$

Fig. 8 A: Confocal image of a double labeled retinal section at pnd 5 showing FGFR2 and calbindin immunostainings. B-D: Higher magnification of the boxed area in A showing double labeled putative amacrine cells. E-G: Confocal images showing FGFR2 and glycine double immunostaining at pnd 5. The inset in G shows FGFR2 immunoreactivity inside DAPI-stained cell nuclei. Abbreviations as in figure 2. Scale bars: $20 \mu \mathrm{m}$ in $\mathrm{A} ; 10 \mu \mathrm{m}$ in $\mathrm{D}$, in $\mathrm{G}$ and in the inset. 
Table 1. Cells double labeled with FGF1, FGFR1 or FGFR2 in adult retinas

\begin{tabular}{|c|c|c|c|c|}
\hline $\begin{array}{c}\text { Marker } \\
\text { (total cells) }^{1}\end{array}$ & Cell type & $\begin{array}{c}\text { Double labeled } \\
\text { (with FGF1) }\end{array}$ & $\begin{array}{c}\text { No double } \\
\text { labeled }\end{array}$ & Percent $^{2}$ \\
\hline Calbindin (584) & Horizontal cells & 582 & 2 & $99.7 \%$ \\
\hline$\beta$-Tubulin III (523) & Ganglion cells & 522 & 1 & $99.8 \%$ \\
\hline $\begin{array}{c}\text { Marker } \\
\text { (total cells) }\end{array}$ & Cell type & $\begin{array}{c}\text { Double labeled } \\
\text { (with FGFR1) }\end{array}$ & $\begin{array}{c}\text { No double } \\
\text { labeled }\end{array}$ & Percent $^{2}$ \\
\hline$\beta$-Tubulin III (508) & Ganglion cells & 503 & 5 & $99.0 \%$ \\
\hline $\begin{array}{c}\text { Marker } \\
\text { (total cells) }\end{array}$ & Cell type & $\begin{array}{c}\text { Double labeled } \\
\text { (with FGFR2) }\end{array}$ & $\begin{array}{c}\text { No double } \\
\text { labeled }\end{array}$ & Percent $^{2}$ \\
\hline Glycine (517) & Amacrine cells & 512 & 5 & $99.0 \%$ \\
\hline GS + Glycine (547) & $\begin{array}{c}\text { Müller cells + } \\
\text { amacrine cells }\end{array}$ & 547 & 0 & $100 \%$ \\
\hline$\beta$-Tubulin III (522) & Ganglion cells & 522 & 0 & $100 \%$ \\
\hline
\end{tabular}

${ }^{1}$ For each marker, the numbers indicate the total of cells counted

${ }^{2}$ Double labeled cells with respect to the total of cells counted for that marker 
Table 2. Cells double labeled with FGF1 or FGFR2 in developing retinas

\begin{tabular}{|c|c|c|c|c|}
\hline $\begin{array}{c}\text { Marker } \\
\text { (total cells) }\end{array}$ & Cell type & $\begin{array}{c}\text { Double labeled } \\
\text { (with FGF1) }\end{array}$ & $\begin{array}{c}\text { No double } \\
\text { labeled }\end{array}$ & Percent $^{2}$ \\
\hline Calbindin (504) & $\begin{array}{c}\text { Developing } \\
\text { horizontal or } \\
\text { amacrine cells }\end{array}$ & 504 & 0 & $100 \%$ \\
\hline Glycine (512) & $\begin{array}{c}\text { Developing } \\
\text { amacrine cells }\end{array}$ & 506 & 6 & $98.8 \%$ \\
\hline $\begin{array}{c}\text { Marker } \\
\text { (total cells) }\end{array}$ & Cell type & $\begin{array}{c}\text { Double labeled } \\
\text { (with FGFR2) }\end{array}$ & $\begin{array}{c}\text { No double } \\
\text { labeled }\end{array}$ & Percent $^{2}$ \\
\hline Calbindin (509) & $\begin{array}{c}\text { Developing } \\
\text { horizontal or } \\
\text { amacrine cells }\end{array}$ & 504 & 5 & $99.0 \%$ \\
\hline Glycine (505) & $\begin{array}{c}\text { Developing } \\
\text { amacrine cells }\end{array}$ & 498 & 7 & $98.6 \%$ \\
\hline
\end{tabular}

${ }^{\mathrm{I}}$ For each marker, the numbers indicate the total of cells counted

${ }^{2}$ Double labeled cells with respect to the total of cells counted for that marker 


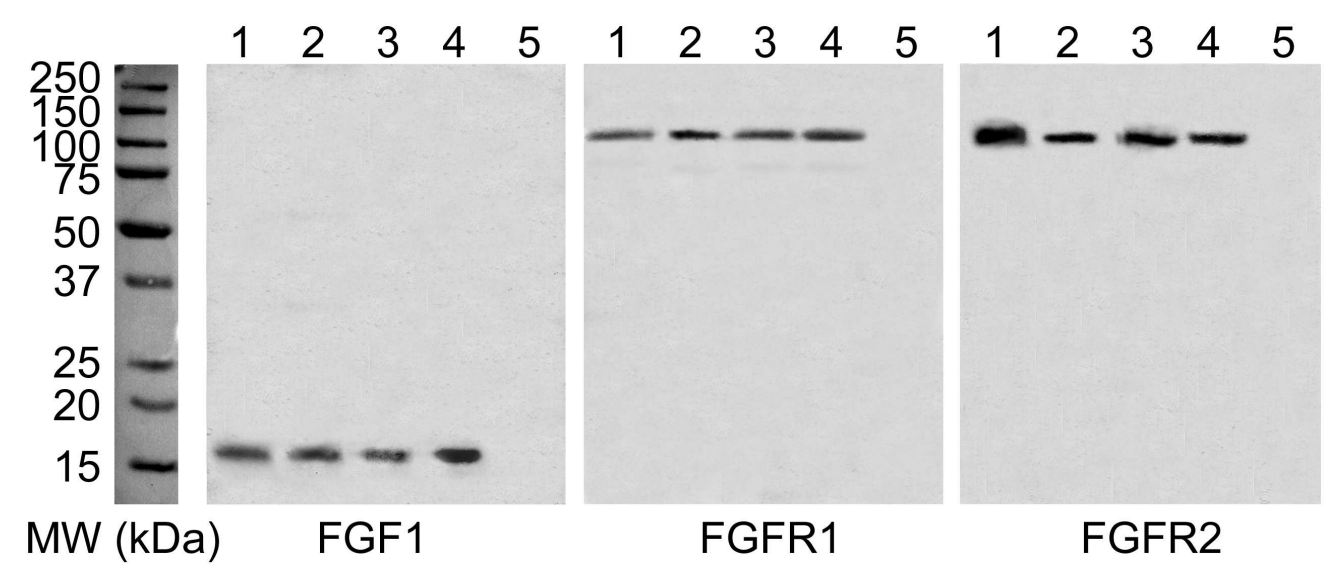

Fig. 1

$128 \times 54 \mathrm{~mm}(509 \times 509$ DPI $)$ 


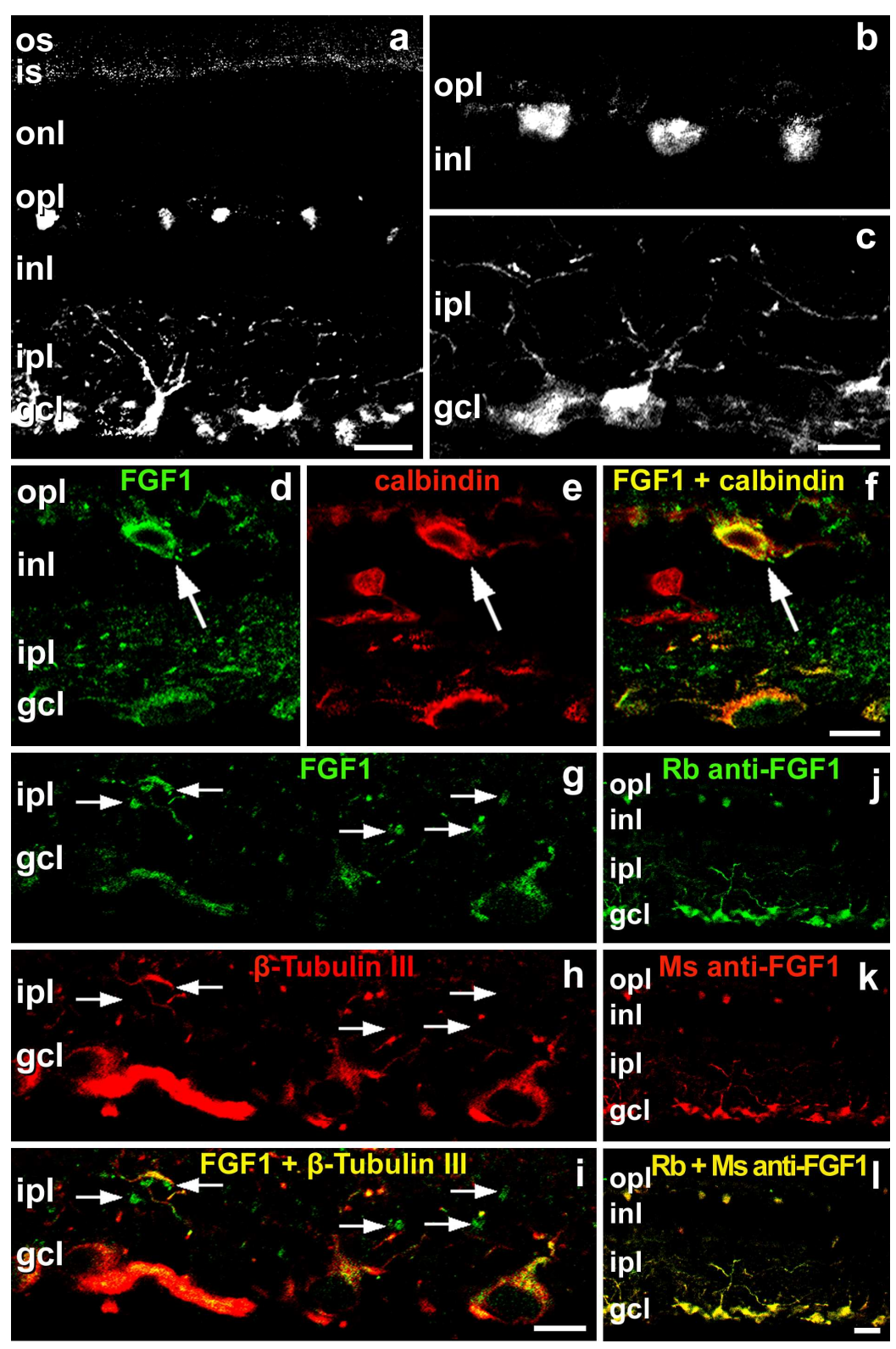

Fig. 2

$129 \times 194 \mathrm{~mm}(372 \times 372$ DPI $)$ 

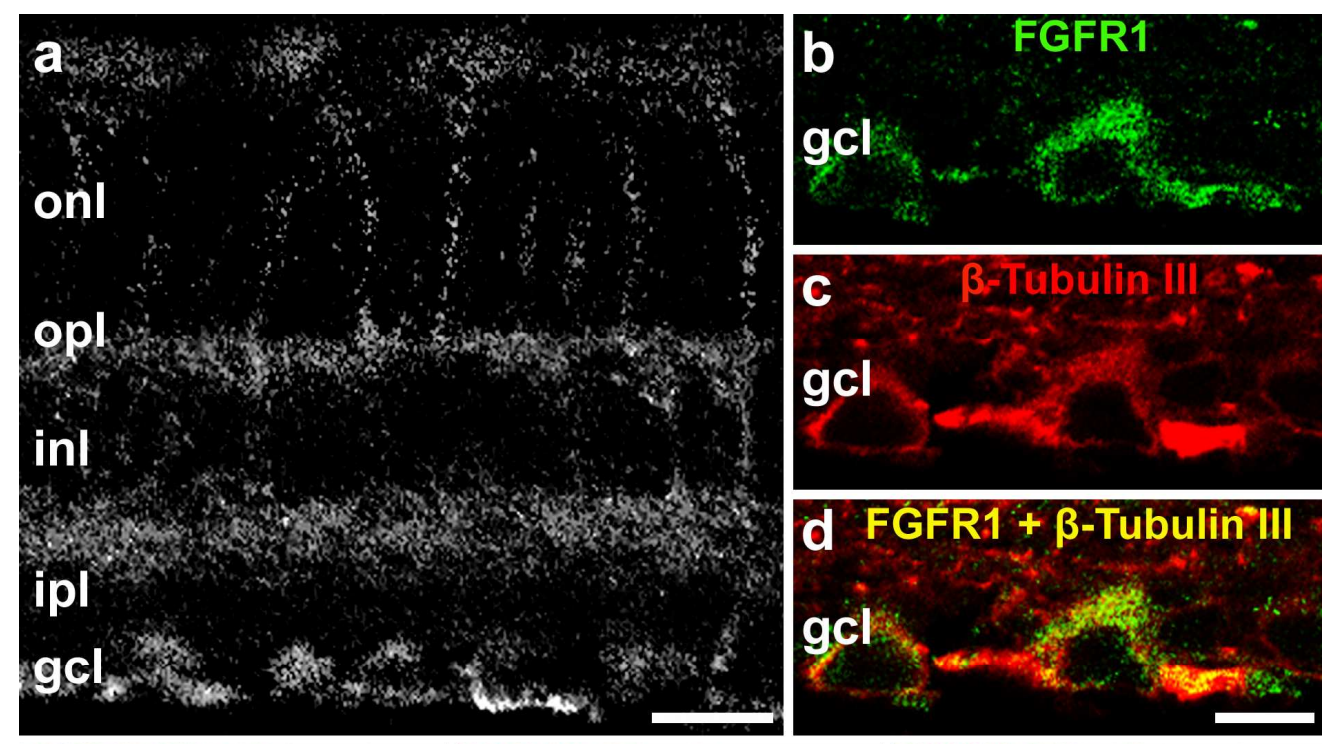

d FGFR1 + $\beta$-Tubulin III
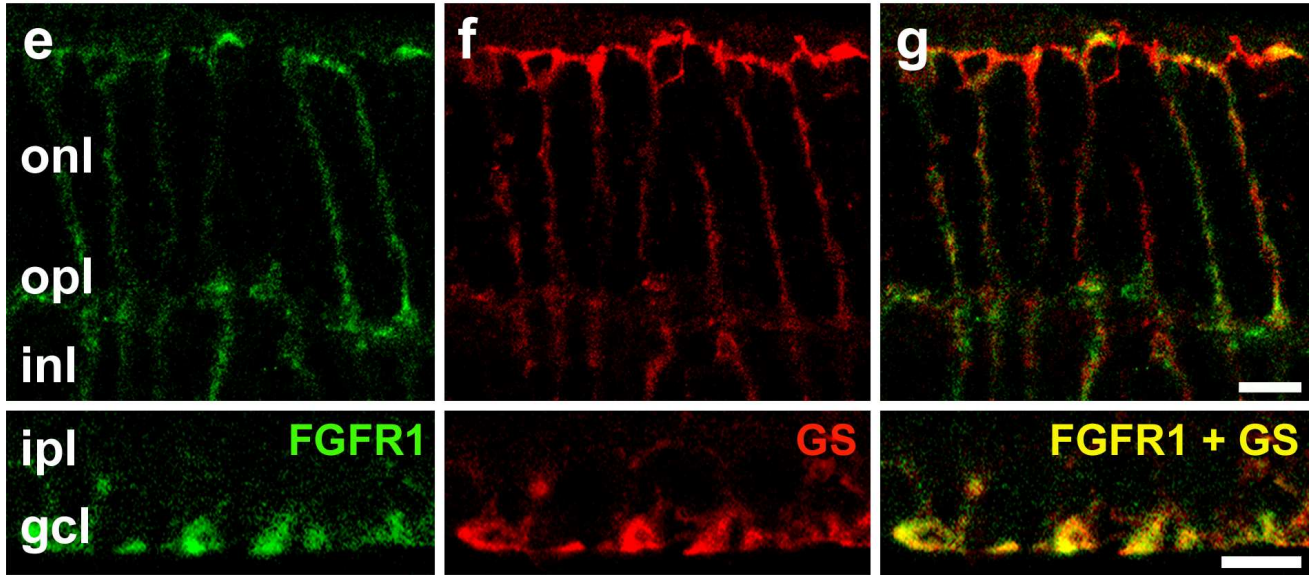

Fig. 3

$129 \times 128 \mathrm{~mm}(372 \times 372$ DPI $)$ 


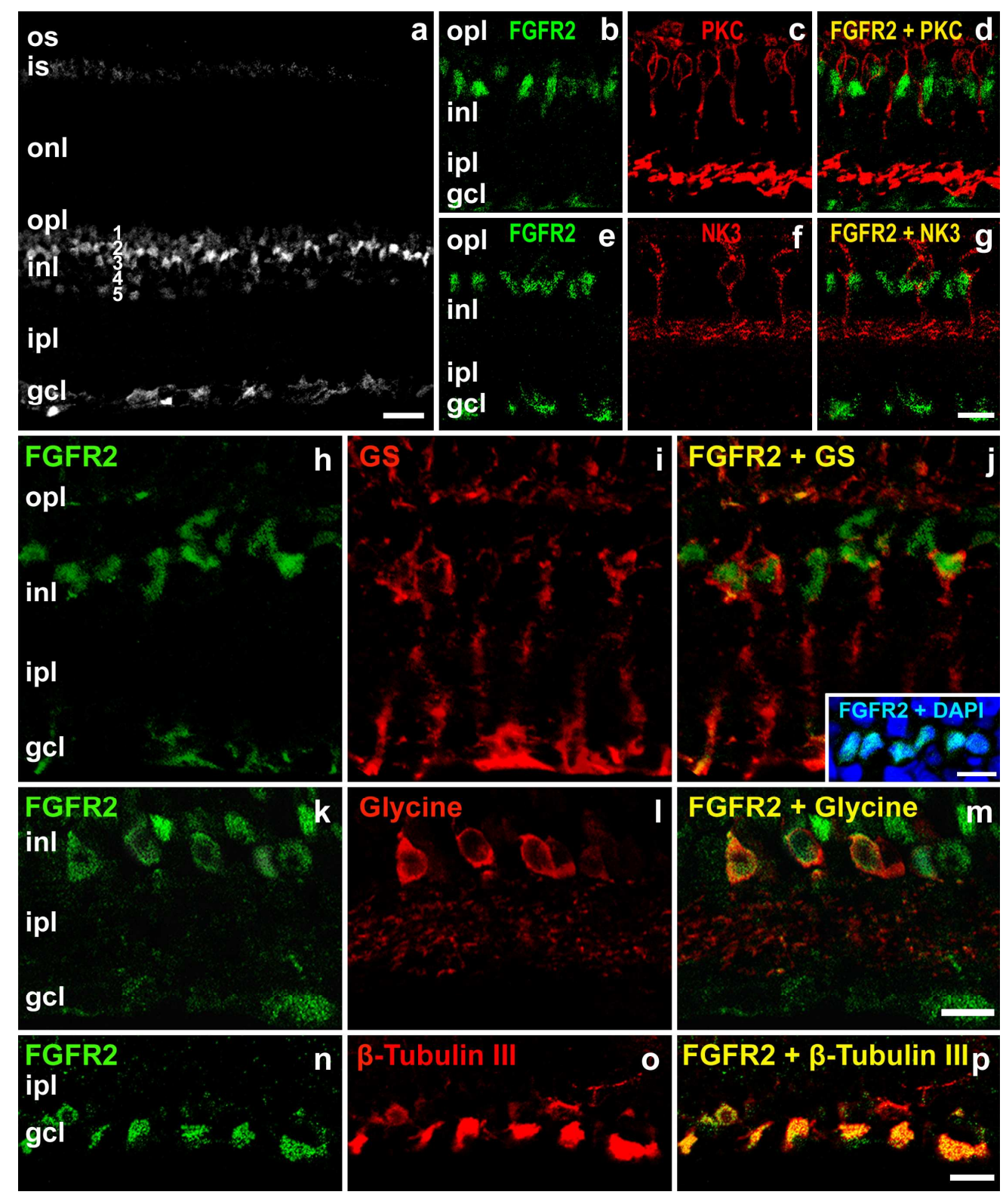

Fig. 4

$174 \times 209 \mathrm{~mm}(330 \times 330 \mathrm{DPI})$ 

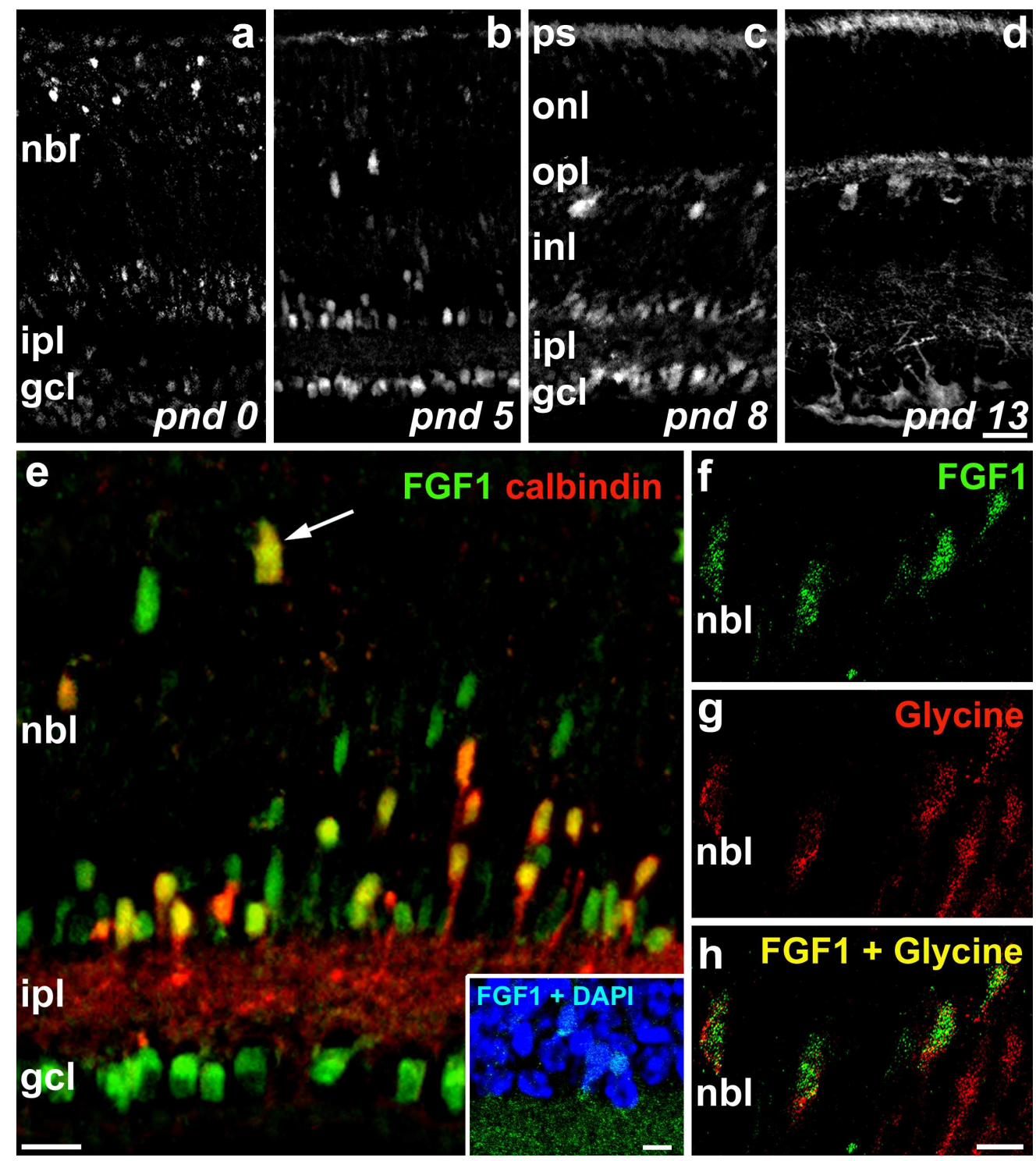

Fig. 5

$128 \times 145 \mathrm{~mm}(463 \times 463 \mathrm{DPI})$ 

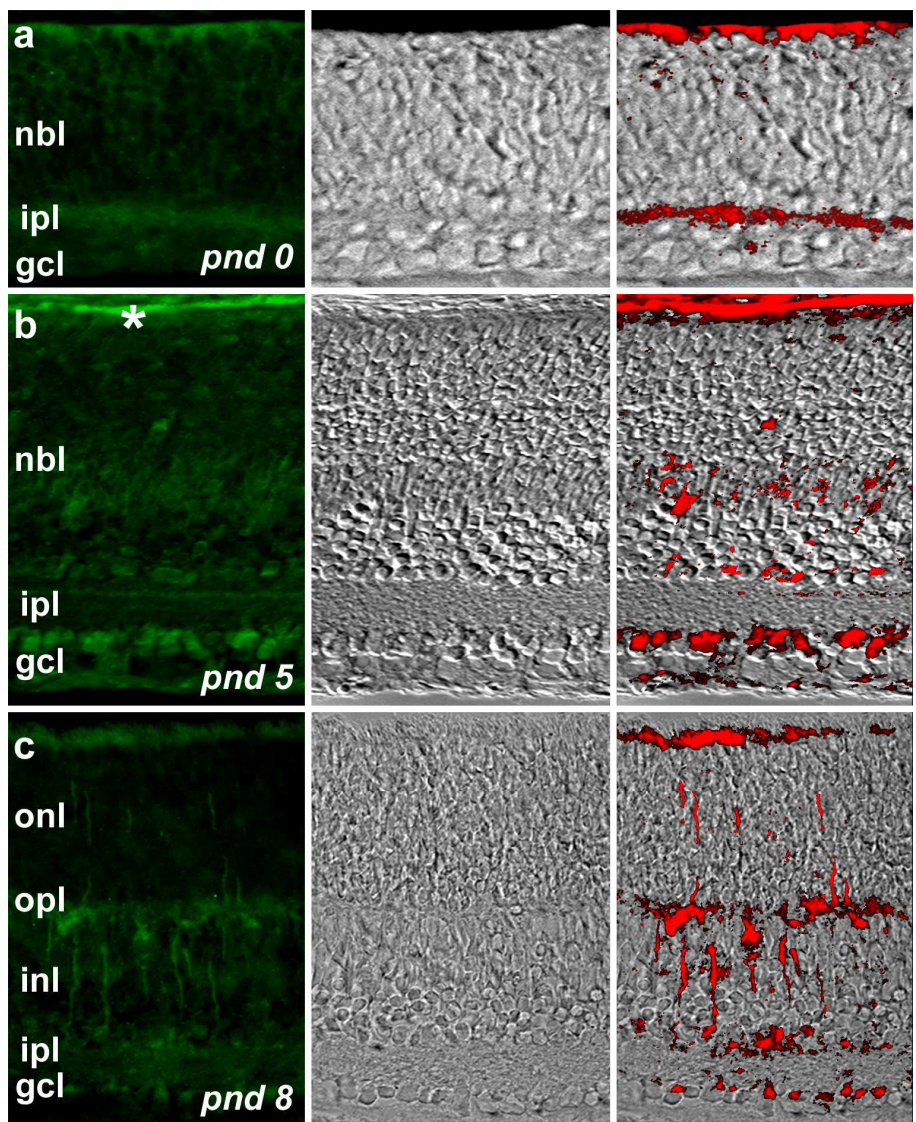

Fig. 6 $129 \times 222 \mathrm{~mm}(300 \times 300$ DPI $)$ 

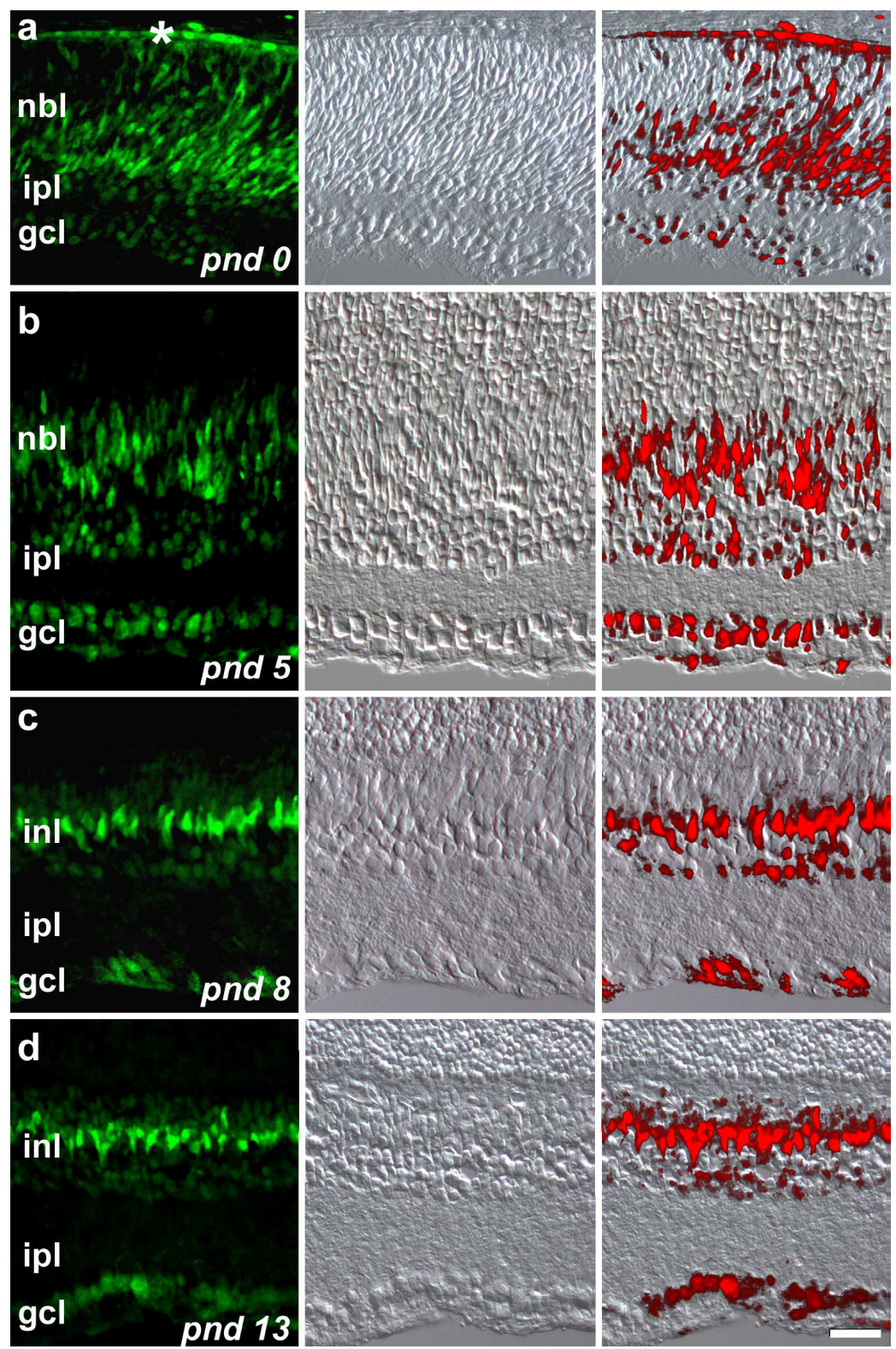

Fig. 7

$129 \times 195 \mathrm{~mm}(300 \times 300$ DPI $)$ 


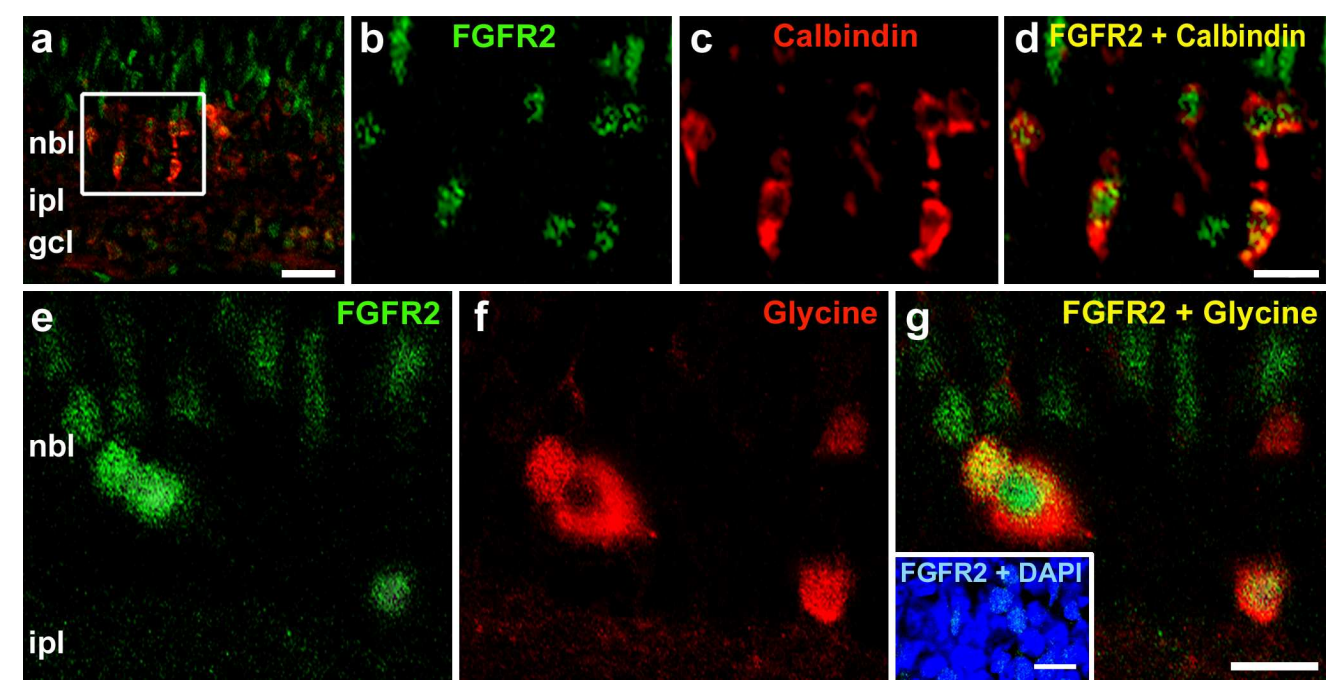

Fig. 8

$173 \times 88 \mathrm{~mm}(298 \times 298$ DPI $)$ 